\title{
THE MYXOMYCETES OF SOUTH-EAST MAHARASHTRA ( INDIA )
}

\author{
R. R. Tembhurne \\ Sangola College, Sangola, Kadlas road, Sangola, Ta-Sangola, Dist.-Solapur, \\ Maharashtra, India. \\ Corresponding author Email : ramesh_tembhurne@rediffmail.com
}

\begin{abstract}
:
During the floristic study of the myxomycetes of this region author come across a number of myxomycetous species. In the ninteenth paper of this study five species of myxomycetes are being discussed . Stemonitis Roth., are being discussed with five species. All species are being reported for the first time from this region.
\end{abstract}

Keywords:

Myxomycetes, slime moulds.

\section{Introduction:}

The Myxomycetes or 'the true slime - moulds' are the fungi like organisms, possess an assimilative phase of free living, multinucleate, mobile mass of protoplasm called as the plasmodium, and a sporulating phase consisting of a mass of spores typically borne in a simple or complex membranous or tough, non-cellular spore case. In addition to spores, often there is a system of free or netted threads forming a capillitium or pseudocapillitium. South-West of Maharashtra -the region under investigation is very rich in biodiversityconstitute the districts Solapur, Satara, Sangli and Kolhapur. The study of myxomycetes was practically neglected from this region. Hence, it was felt to undertake the study. Out of the investigates carried out, it is the 19th paper in this series in which, about five species belongs from one genera are being discussed as under. INTRODUCTION: The Myxomycetes or 'the true slime moulds' are the fungi like organisms, possess an assimilative phase of free living, multinucleate, mobile mass of protoplasm called as the plasmodium, and a sporulating phase consisting of a mass of spores typically borne in a simple or complex membranous or tough, non-cellular spore case. In addition to spores, often there is a system of free or netted threads forming a capillitium 
or pseudocapillitium. South-West of Maharashtra the region under investigation is very rich in biodiversity-constitute the districts Solapur, Satara, Sangli and Kolhapur. The study of myxomycetes was practically neglected from this region. Hence, it was felt to undertake the study. Out of the investigates carried out, it is the 19th paper in this series in which, about five species belongs from one genera are being discussed as under.

\section{Material and Method:}

The present work is based on myxomycetous floristic exploration from the region. An extensive and intensive field work was undertaken to collect the maximum number of specimens of myxomycetes. Visits to different localities were made frequently. Localities for visit were selected so as to cover the maximum representation of the area under investigation. Repeated visits were made to some of the localities for the collection of the specimens. Specimens were collected along with their natural substrates. For the preservation of specimens, empty cegarates boxes found to be very suitable, convenient, easily available, easy to handle and economical. Paper trays of the proper size were prepared so as to get it fit inside the box tray. As per the spreading of the specimen, its natural substrate was cut into suitable size and glued with the fevicol adhesive in the centre of the paper tray. Each box was provided with field notes of respective specimen. The accession number was written on the specimen box and on the paper tray also, and entered in accession register. After observation, specimen boxes were stored and placed in 'Generic' boxes provided with naphthalene ball to prevent insect entry. Generally specimen boxes were carried to the field to preserve the specimen intact. Sometimes because of heavy collection, specimens were brought to the laboratory on their natural substrate, in a special handling basket, so as not to disturb them. Then they were preserved. In rainy season, the collected specimens were dried in the incubator or and oven at $40^{\circ} \mathrm{C}$. But sun drying was found to be most suitable for maintaining natural characters. Artificial drying sometimes leads to 
the shrinkage of weak and flaccid stalk, hardening of wet sporangia and cracking of peridium. All the specimens were identified and confirmed with the help of Martin and Alexopoulos (1969), sometimes, Lister (1925), Hagelstein (1944), Farr (1976), were followed. Monographs on Indian Myxomycetes of Thind (1977), Lakhanpal and Mukerji (1981), were of almost indensepensible for final confirmation. Concerned liteture in this regards were also studied.

\section{Result and Discussion:}

1. STEMONITIS FUSCA Rost Mag. Bot. Romer \& Usteri, 1, (2), 26, 1787. COLLECTION EXAMINED: RRT / 8114, Sept.-2004, Radhanagari; 8796, 8799, 8961, July-2006, Ichalkaranji; 8674, 8804, 8805, 8806, 8809, 8813, 8816, July-2006, Hatkanangale; 8698, 8792, 8793, 8794, July2006, Karveer, Dist.- Kolhapur; 8439, 8448, 8449, 8450, Oct.-2005, Pratapagad, Dist.-Satara; 8832, 8833, 8834, 8836, July-2006, Kawathemahankal; 8686, 8976, 8978, 8979, 8981, 8982, 8985, 8990, 8991, 8994, 8996, 8998, 8999, July-2006, Atapadi, Dist.-Sangli; 8705, July-2006, Tembhurni; 8854, 8857, 8858, 8859, 8860, 8862, July-2006, Nimgaon-Tembhurni; 8775, 8881, 8882, 8885, 8886, July-2006, Lamboti-Mohol; 8904, 8907, 8908, 8910, 8913, 8914, 8916, 8917, 8918, 8919, 8920, 8923, 8924, 8925, 8930, July-2006, Madha; 8944, 8945, 8972, 8973, June-2006, Pandharpur, 8679, 8680, 8681, July-2006, Anagar, Madha, Dist.-Solapur. On dry dead wood of angiospermic plants and on dry sugarcane straw.

2. DISTRIBUTION: INDIA: Assam (Agnihothrudu, 1959); H. P. (Lakhanpal \& Mukerji, 1981); Karnataka (Indira, 1968); M. S. (Nanir, 1978); Orissa (Ghosh \& Dutta, 1962); T. N. (Agnihothrudu,1956); U. P. (Thind, Sohi \& Manocha, 1957); W. B. (Thind, 1977). The species is characterized by large clusters of dark violaceous brown, long sporangia, abundant primary branches in capillitium, close meshed surface net with abundant spinulose free ends ; reticulate verrucose spores. The present population is quite similar to S. fusca var. fusca Rost. Indian population described by Thind (1977), have larger size of fruiting. Stemonitis fusca Roth. can be comapared with S. nigrescens Rex. S. nigrescens Rex. is differentiated by its from smaller clusters of smaller sporangia, much 
shorter stipes and slightly larger spores, meshes of surface net are quite irregular.

3. STEMONITIS HERBATICA Peck Ann. Rep. N. Y. State Mus 26, 75, 1875. COLLECTION EXAMINED: RRT/ 8800, 8851, July-2006, Nimgaon, Tembhurni, Dist.-Solapur. On dry sugarcane straw. DISTRIBUTION: INDIA: Assam (Agnihothrudu, 1959); Delhi (Lakhanpal and Mukerji, 1981); Maharashtra (Nanir, 1978); Punjab (Thind, 1977); T. N. (Agnihothrudu, 1956; Indira, 1968); U. P. (Thind and Rehill, 1959); West Bengal (Lodhi, 1934). The species can be marked by its short stipe, cylindrical violaceous brown sporangia. The species occurs mainly on living plant parts. The populations described in the present work are rarely on living plant and do not have reticulate spores, but mostly the warts are in lines. The populations is quite similar to Inidan collections described earlier by Thind, (1977), and Lakhanpal \& Mukerji, (1981). S. herbatica (Peck) is close to S. flavogenita (Jahn). However S. flavogenita (Jahn) possesses a somewhat longer stipe and occurs chiefly on dead wood; besides the surface net of its capillitium is usually fugacious at the top as the sporangia mature. The columella is reported to be usually expanded at the top in this species.

4. STEMONITIS MUSSOORIENSIS Martin, Thind \& Sohi Mycologia 49 : 128-130, 1957. COLLECTION EXAMINED: RRT/ 8441, 8553, Oct.-2005, Pratapagad, Dist.-Satara. On dry sugarcane straw. DISTRIBUTION: INDIA: U. P. (Thind \& Sohi,1950); M. S. (Nanir, 1978). The species is characterized by small sporangia, large meshed surface net of the capillitium and prominently verrucose large spores, 8.3 - $12.4 \mathrm{um}$ in diam. In all these respects it is easily differentiated from S. splendens Rost. which is its near relative. S. splendens Rost. species is distinguished by densely gregarious long sporangia which are flattened above, columella tapers to a fine flexuous or tortuous thread above, the capillitium which arises only from a few branches from the columella are uniform with polygonal meshes, the spores are minutely but distinctly verrucose. 4.

5. STEMONITIS NIGRESCENS Rex Proc. Acad. Phila, 43, 392, 1891. COLLECTION EXAMINED: RRT / 8115, 8117, Sept.-2004, Radhanagari; 8694, July-2006, Hatakanangale; 8688, 8689, 8690, 8691, 8692, 8696, 8697, 8797, 8798, 8801, 8802, 8803, July-2006, Ichalkaranji, Dist.- 
Kolhapur; 8438, 8442, 8443, 8444, 8445, Oct.-2005, Pratapagad; 8451, Oct.-2005, Mahabaleshwar, Dist- Satara; 8719, 8838, 8840, July-2006, Kawathemahankal; 8977, 8979, 8984, 8985, 8986, 8988, 8989, 8995, 8997, 8998, July-2006, Atapadi, Dist.-Sangli; 8710, 8922, 8929, 8909, July-2006, Anagar, Madha; 8906, 8911, 8912, 8923, 8926, 8928, 8933, July-2006, Madha; 8954, 8967, 8969, 8970, 8975, June-pandharpur; $8700,8845,8846,8849,8850,8853,8855,8856,8861,8862$, July2006, Nimgaon, Tembhurni; 8762, 8769, 8770, 8773, 8774, 8777, 8779, $8781,8782,8783,8784,8785,8888,8891,8894,8896,8897,8899$, 8900, July-2006, Lamboti, Mohol; 8713, 8714, 8715, 8716, July-2006, Vairag; 8748, July-2006, Mangalvedha, Dist.-Solapur. On dead decaying wood of angiospermic plants and dry sugarcane straw. DISTRIBUTION: INDIA: Assam (Agnihothrudu, 1959); H. P. (Lakhanpal \& Mukerji, 1981); Karnataka (Indira, 1968); Maharashtra (Nanir, 1978). S. nigrescens Rex is very close to S. fusca Roth. It differs from the latter in having smaller clusters, smaller sporangia, much shorter stipes and slightly larger spores. Meshes of the surface net are rather small and very uniform in S. fusca Roth., however they are small to large and quite irregular in S. nigrescens Rex. In colour and external appearance, S. nigrescens Rex, is similar to S. mussooriensis Martin, Thind and Sohi, but differs from it in having fine meshed surface net and reticulately warted, smaller spores. G. Lister (1911), Hagelstein (1944), treated it as a variety of Stemonitis fusca Roth. Martin \& Alexopoulos (1969), recognized it as a distinct species. It is differentiated from S. fusca Roth., in its small cluster of smaller sporangia, shorter stipe and larger spores with more or less strong marking.

6. STEMONITIS PALLIDA Wingate In Macbr., N. Am. Slime-Moulds, 123, 1899. COLLECTION EXAMINED: RRT / 8957, 8960, June-2006, Pandharpur; 8905, July-2006, Madha, Dist.-Solapur. On dry sugarcane straw. DISTRIBUTION: INDIA : H. P. (Lakhanpal \& Mukerji, 1981); Karnataka (Indira, 1968); Maharashtra (Nanir, 1978); U. P. (Lodhi, 1934 ; Thind \& Rehill, 1959). The species is very close to S. herbatica Peck and S. flavogenita Jahn. S. herbatica Peck is differentiated from the other two species only by its possessing persistent surface net at the top and by its more herbaceous habit. S. flavogenita Jahn differs from S. pallida Wingate in having larger sporangia in closely fasciculate clusters. A Four Monthly Peer Reviewed Journal VISHWASHANTI MULTIPURPOSE SOCIETY (GLOBAL PEACE MULTIPURPOSE SOCIETY) 
Whereas om S. pallida Wingate sporangia are smaller and gregarious and the columella ends abruptly at the top. The population described herein at first glance seems to be species of Comatircha Preuss. But it differs in having hollow stipe and capillitial surface net. Whereas, in Comatricha Preuss the stipe is solid and fibrillar and lack peridial net.

\section{Conclusion:}

In this region collect the maximum number of sample of myxomycetes of these only five species are being described and identified that are as

1. Stemonitis fusca Rost.

2. Stemonitis herbatica Peck.

3. Stemonitis mussooriensis Martin, Thind and Soni.

4. Stemonitis nigrescens Rex and

5. Stemonitis pallida Wintage. All these species first time described and identified from the said area.

\section{Acknowledgement:}

Authors are thankful to knowledge providers for providing valuable information, who has guide to me and gives moral support to do this work .The authors also wish to state that prior informed consent was taken from the knowledge providers as per his guidelines.

\section{Reference}

Dhillon S.S. \& N.E. Nannanga-Bremekamp. 1978: Notes on some Myxomycetes from North-west part of the Himalaya. K.Ned. Akad. Wet. Proc. C, 81, 141-149.

Farr M.L. 1976: Flora Neotropics, Mon. 16. Myxomycetes. The New York Bot. Gard. N. Y. Hagelstein R. 1944 : The Mycetozoa of N. America, Publ. by Autor Mineola. New York. 
Kowalski D.T. 1970: A new Folicolous species of Licea. Mycologia, 62, 1057. Lakhanpal T.N. and K.G. Mukerji. 1981: Indian Myxomycetes. J. Cramer. pp. 530.

Lister A. and G. 1925: A Monograph of Mycetozoa. by A. Lister, 1984 (ed. 2., 1911; ed. 3., 1925, revised by G, Lister) British Museum. (Natural History) London.

Martin G.W. \& C.J. Alexopoulos. 1969, The Myxomycetes, Iowa City press. Martin G.W., C.J. Alexopoulos and M.L. Farr. 1983: The Genera ofMyxomycetes. Univ. Iowa Press. Iowa City.

Nanir S.P. 1985: Contribution to the knowledge of Myxomycetes from India-III B. Indian bot. Reptr., 4(1), 42-45.

Nanir S.P. and B.G. Rokade. 1987: Myxomycetes of Marathwada-I (Ceratiomyxomyxales, Liceales and Trichiales) Mar. Univ. Jour. Sci. p. 12.

Nanir S.P. and B.G. Rokade. 1993: Myxomycetes of Jalgaon and Dhule District (Khandesh): India. Abst.N.C.R.A.P. p. 14. Abs.

Thind K .S. 1977: The Myxomycetes in India pp. 452, I. C. A. R., New Delhi. 

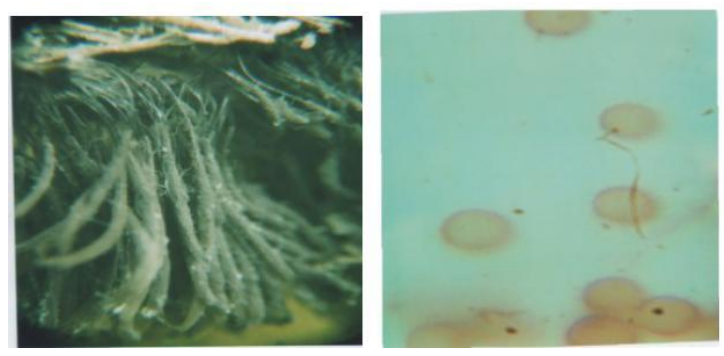

1. Stemonitis fusca
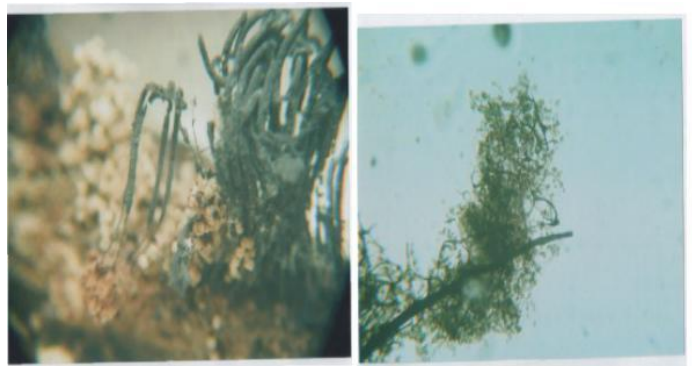

3.Stemonitis mussooriensis
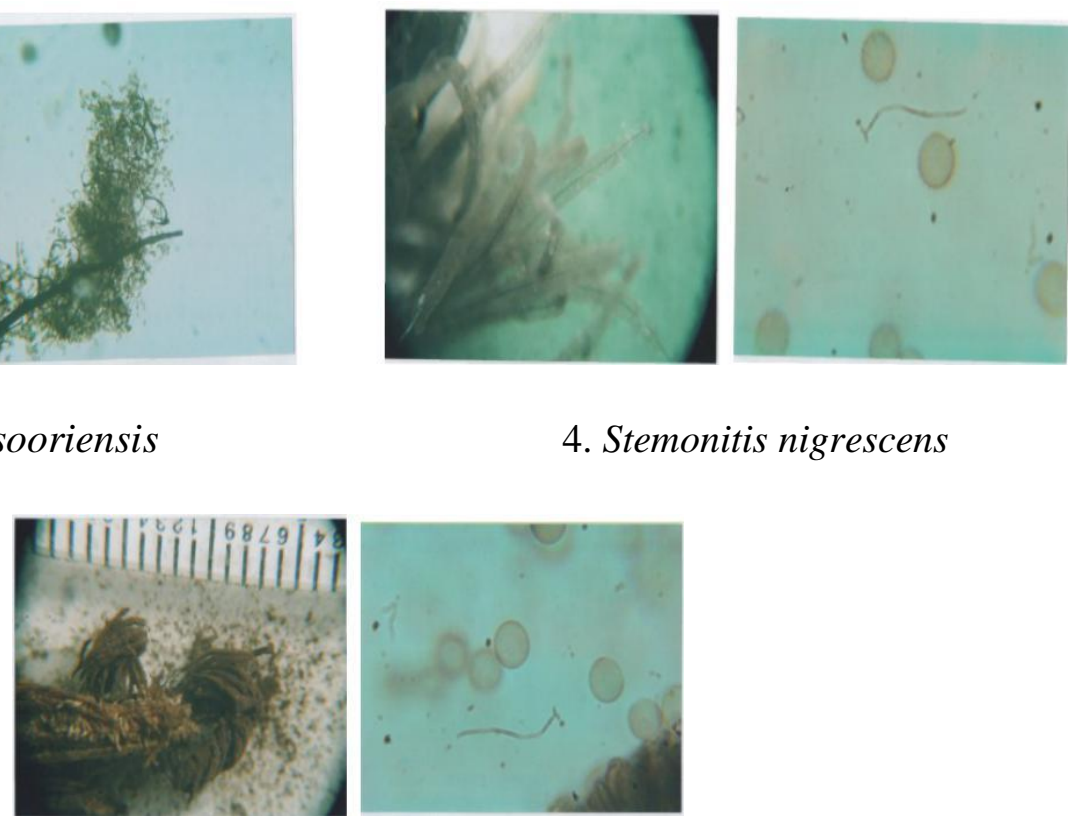

4. Stemonitis nigrescens

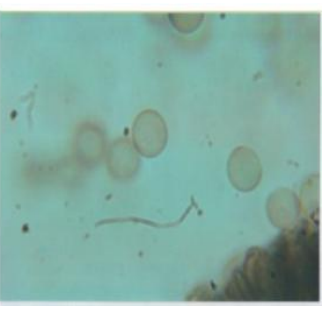

5. Stemonitis pallida

2. Stemonitis herbatica

$s$

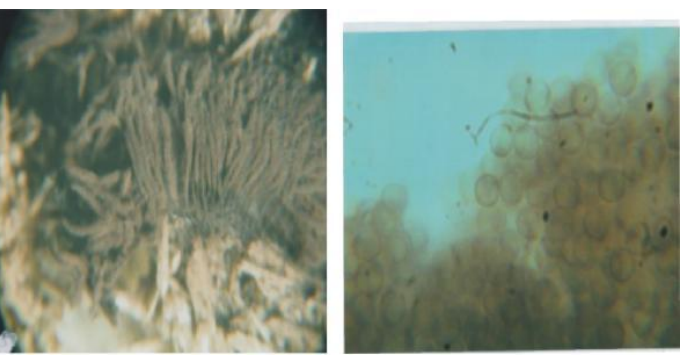

